\title{
THE MUSEUM OF ETHNOGRAPHY'S HABAN CERAMICS IN BUDAPEST
}

\author{
Gabriella VIDA \\ Museum of Ethnography \\ Kossuth tér 12, H-1055 Budapest, Hungary \\ E-mail: vida@neprajz.hu
}

\begin{abstract}
The Ceramics Collection in the Museum of Ethnography contains around 2300 faience objects, of which 60 are classical Haban vessels and at least 1500 are Late Haban pieces. There are examples of transition between Haban style periods and exceptions that make this collection unique, compared to other collections of Haban objects. The largest collection in Hungary of Late Haban objects is also found here. The study presents the most interesting pieces, how the larger groups entered the collection, and the different object groups. It describes 45 archaeological finds unearthed on the sites of three Haban settlements, that provide valuable information on the technique used to make them. Based on the ornamentations on a Haban product from 1732 we can date and identify two types from Nagylévárd (now Vel'ké Leváre, Slovakia): one with coloured painting and the other one with blue ornamentation on a white ground). The study calls for a debate on ceramics history to clarify questions related to both Haban and lead-glazed pottery produced in a micro-region by the German-speaking people living in the mining towns in the first half of the $18^{\text {th }}$ century. Late Haban ware was popular throughout the entire territory of Hungary in the $18^{\text {th }}$ to $19^{\text {th }}$ centuries. Examples have been found in almost all micro-regions.

Keywords: Late Haban, waster shard, Haban court, Habanszki Dvor, potter's sign panel, faience technique, Nagylévárd coloured type, Nagylévárd blue and white type, provenance, faience manufactory
\end{abstract}

Around 2300 pots in the Museum of Ethnography are tin-glazed faience. ${ }^{1}$ Approximately 400 of them were made in Modor, or in the Czech town of Vyşkov. The museum possesses a few bowls from Zittau and Gmunden, and around two hundred pieces from various Austrian and other Czech manufactories. The remainder are the work of the Habans, Anabaptist Protestants who moved to Hungary mostly after 1620, settling mainly in the area of Nyitra (Nitra, Neutra, now in Western Slovakia), Trencsén (Trenčín, Trentschin, now Western Slovakia) and Pozsony (Bratislava, Pressburg, now Western Slo-

${ }^{1}$ In 2010 a multi-year Haban research project was launched under the direction of the Hungarian National Museum and the Museum of Applied Arts and with the participation of the Museum of Ethnography. 
vakia), and in smaller numbers to Erdély (Transylvania, Siebenbürgen, now Romania) and Sárospatak (North-eastern Hungary). Only 60 of these pieces are from the classical period, the great majority are Late Haban and Post-Haban ware. Almost all the objects mentioned can be found at http://public.neprajz.hu/neprajz.01.03.php?bm=2\&kv=7025542, or in the online collections on the Museum of Ethnography's website under the heading of Household Collection.

\section{THE ACQUISITION OF HABAN VESSELS}

As a consequence of their ethnological research methods, ethnographic collections expand primarily through local collecting, where special emphasis is placed on the occasions and way in which the object was used, the place where it was stored, its purchase, its prestige, and notes are made on the social status of its owners. In the case of the Haban vessels, we have such data only for pieces from the Late Haban period. This is because these pieces reached the rural population in the $18^{\text {th }}$ to $19^{\text {th }}$ centuries, and were still there in their original place with their users at the time when ethnographic collecting began, in the 1870 s to 1880 s. Whole collections of them were found in the late $19^{\text {th }}$ century, especially in areas that could be reached along the Danube and its tributaries, and surprisingly also in a few isolated micro-regions (KRESZ 1977: 26; KRESZ 1984). In the Kisalföld region (Northwestern Hungary) in the wealthier peasant homes, jugs were kept on decorative hooks above the table in the corner, and were still used for drinking wine in the first decades of the $20^{\text {th }}$ century (Inv. n. 66.68.41) ${ }^{2}$. A rare example of Haban vessels collected on the spot is a big jug with the date 1750 (Inv. n. 66.39.71), decorated with a skull on the side opposite the handle and placed among objects used for funerals. ${ }^{3}$ It probably belonged to a funeral society. In the case of vessels from the classical Haban period, we have no information on the places of origin and use, the financial status of the user family or the prestige of the object. There are, of course, exceptions: in 1968 we purchased a big piece dated 1703, a folk-style jug with a narrow mouth that had been part of a family inheritance (Inv. n. 68.215.1-2). Typically, Haban objects acquired from private persons did not come from owners in villages or small towns but from aristocrats (from Baron Albert Nyáry for example), or from members of the wealthy bourgeoisie or city intelligentsia (BENDA 2004: 138-144). In 1913, the daughter of a lawyer from Pécs sold a sizeable collection to the museum. Most of the items are from the Late Haban period, but there are also several fine classical pieces among them. A large plate with the monogram I B and the year 1710 (Inv. n. 101152) has two, almost identical, known parallels. One is in the Museum of Applied Arts and the other is from the largest private Haban collection that belonged to the renowned Haban researcher and art historian Béla Krisztinkovich, now in the possession of his inheritors. ${ }^{4}$ Together with this piece, they bought a large bokály (pear-shaped jug) that bears the emblems of a

\footnotetext{
${ }^{2}$ According to the inventory card of the vessel, collected in Csoma.

${ }^{3}$ The jug was collected by Marietta Boros in Szentgotthárd; it had been brought there through marriage from the area around Pozsony (Bratislava, now Slovakia).

${ }^{4}$ Museum of Applied Arts: Inv. n. 2959, RÉTi 2007: 76, object No. 130, and from the Réti-Krisztinkovich Collection: RÉTI 2007: 76, object no. 129.
} 
tailors' guild and the date 1747 (Inv. n. 101155). Since the object was collected without data, we know nothing about how a guild vessel came into the possession of the family of a Pécs lawyer. Our only stemmed small bowl with white glaze and date 1701 was also part of that group (Inv. n. 101153). In 1897130 objects were purchased for the collection, 16 of which were tin glazed vessels. We can read on the inventory card of one of the large jugs (Inv. n. 28880): "The jug, and the vessels inventoried successively up to no. 28896 are from the village known as 'Habanszki Dvor' (near Szobotist), where such vessels were produced in the past: however, they are no longer made there." In the places where Habans once lived, their settlements are still known as "Haban courts" (KREsz 1982: 312) The Habanszki Dvor mentioned on the card must have been the area of Szobotist (up to 1899 Szobotist, then Ószombat, Sobotište, now in Western Slovakia) where the Habans lived. To the best of my knowledge, this collection is the only one that is known precisely to have come from a place formerly inhabited by Habans. It can be safely assumed that it was also made there. This is therefore one of the rare cases of collections made on the spot. The group is highly varied in quality, shape and decoration. It cannot be generally characterised. It includes a number of dated pieces from the $18^{\text {th }}$ century, but the majority are presumably from the $19^{\text {th }}$ century. None of the items have monochrome decoration. The pear-shaped jugs are rather rounded than slim, their main common features are minute decorative lines made of alternating yellow and green dots between mainly dark brown crosses. One large jug is from 1781 (Inv. n. 2888). (Fig. 1) and one ring-shaped flask (Inv. n. 28882) (Fig. 2) has classical elements from the second half of the $18^{\text {th }}$ century, the others are the products of a later decoration period. It is worth mentioning that the new decorative elements already appear on a plate dated 1764 (Inv. n. 28888) and show a matured style. No data has survived on the circumstances of the collecting, although it would be important to know from how many families these vessels of such widely differing styles and periods were collected. Without this information we are unable to properly interpret the group of objects.

The majority of our Haban objects have had an adventurous history within Hungarian exhibitions, public collections and museums. Most of them were shown at one or other of the big world expositions in the second half of the $19^{\text {th }}$ century, some of them at several. After the expositions closed, they entered the Museum of Applied Arts and from there they were transferred to the Museum of Ethnography that had become an independent institution (CSUPOR 2000: 264). Unfortunately, the relevant data was not transferred together with the objects and, as a result, much information on their origin and the provenance has been lost. The most frequent manner of acquisition in this object type is purchases from collectors. However, in most cases there is no information at all on the original provenance of the object. ${ }^{5}$ One of our most famous examples is a wide-mouthed

${ }^{5}$ The famous collection of Vince Wartha, chemist and professor at the University of Technology, a renowned researcher in the late $19^{\text {th }}$ century on ceramic glazes; he accumulated the collection for experimental and educational purposes in the Department of Chemistry and Technology at the University of Technology. In 1948 the collection was transferred to the Museum of Applied Arts and from there part of the collection was taken over by the Museum of Ethnography. Out of around 900 vessels, 150 were tin-glazed, and a number of these were Haban work. The jug with a marbled decoration and the date 1707, Inv. n. 51.30 .117 can be linked to the classical Haban period. - No records were kept on where and when individual pieces were collected, the name and social position of the collector. 
jug (Inv. n. 101912) from the collection of János Csermely, dated 1700. Three rabbits joined at the ears, a representation of the Holy Trinity, can be seen on it. This portrayal can be traced back to the $12^{\text {th }}$ century and has been found among a number of peoples in Europe. In Hungary it is known from a few churches of the Árpádian age; later it was used by the Habans as a way of portraying the Holy Trinity without human figures (CSEMEGI 1957: 8; VIDA 2008: 210). (Fig. 3) In the first years of the $20^{\text {th }}$ century, on a number of occasions the museum purchased a large number of exceptionally beautiful and early objects from József Fejér, a dealer in Brassó (Braşov, Kronstadt, now Romania). However, the objects he brought were not only from Transylvania, as indicated by a Haban jug with a pewter lid dated 1690, originally from Eperjes (Prešov, Preschau, Eastern Slovakia) (Inv. n. 34100). In 1903 and 1904, the Museum of Ethnography purchased from him a batch of 1500 items, containing stove tiles, textiles and vessels. They included twelve fine classical Haban pieces (Inv. n. 80900-80912), as well as Late Haban products. As a consequence of nationalisation, in 1951 three large legacies came into the possession of the museum. It was at this time too that the collection of Elemér Kund (Inv. n.s 51.31.1 51.31.338) became part of the Ceramics Collection of the Museum of Ethnography. One unusual piece in this collection was a pear-shaped jug dated 1724, with unique decoration (Inv. n. 51.31.500). We have twelve classical Haban pieces from the collection of Mrs Tibor Keresztes, a few of which merit special mention. They include the only plate in our possession made by the Odler family (Inv. n. 70.37.175). They also made one of the museum's three round-bottomed, cardinal's hat formed dishes, decorated on the rim with a monogram in a closed wreath and the date 1747 (Inv. n. 70.37.177). The first object with a genre scene showing Slovak costume is a wide-mouthed jug from 1760 (Inv. $\mathrm{n}$. 70.37.188). One of our jugs decorated with blue and white marbling is also from her ( Inv. n. 70.37.237). In 1991, the museum purchased a fluted jug that we believe originated from Alvinc (Vințu de Jos, Winzendorf, now Romania), the Haban settlement in Transylvania; with its slip coating, blue ground colour glaze and rich decoration, it is an outstanding piece in the collection (Inv. n. 91.45.1). (Fig. 4)

\section{ARCHAEOLOGICAL FINDS}

One especially valuable group of acquisitions was a collection of 45 numbered and labelled archaeological fragments, ${ }^{6}$ given by the Czech researcher Heřman Landsfeld to Mária Kresz in July 1962. There is no document in the Archive of the Museum of Ethnography recording the fact of the gift. The fragments are from three settlements: a single piece from Gósfalva (Kosolna, Košolná, now Western Slovakia), the remainder from Szobotist (up to 1899 Szobotist, then Ószombat, Sobotište, now Western Slovakia) and Holics (Holíč, Holitsch, earlier Weisskirchen, now Western Slovakia) (Inv. n.s 2013.54. 1 - 2013.54. 45). The fragment (Inv. n. 2014.54.1) from Kosolna is a handle pressed in a

\footnotetext{
${ }^{6}$ Mária Kresz (Berlin, 1919 - Budapest, 1989) was for decades head of the Ceramics Collection, a renowned researcher. Heřman Landsfeld carried out archaeological excavations on the territory of former Haban settlements.
} 
small mould, a shell-shaped half-finished piece of pottery; according to the information provided by Heřman Landsfeld it dates from 1663. The material from Szobotist is of three kinds: fragments with tin and lead glaze, and kiln furniture. Among them are fragments of the foot of two small glazed jugs: one (Inv. n. 2013.54.6) has a white tin glaze outside and inside, the other (Inv. n. 3013.54.8) has a white glaze on the inside, but the outside has a white sprinkle glaze on a manganese purple base, evidence that the Habans also made wares with such decoration. Landsfeld dated a small fluted bowl and a small fluted jug with a wide mouth to between 1660 and 1670; no layer of engobe can be seen beneath the glaze on these pieces. A thin layer of what appears to be slip can be seen on the other faience fragments, but it could also be unfired tin glaze. There are also two triangular stilts of different size: they are made from the same material as the body of the vessels (Inv. n.s 2013.54.4, 2013.54.18). (Fig. 5) However, the unglazed or lead-glazed fragments of pieces from Szobotist intended for household use are of strikingly different material: they are thick-walled pieces thrown from rough-grained clay full of grains of stone, fired to a brick-red colour. Over time, buried under the ground the thin lead glaze became iridised. Landsfeld dated one of the cooking pot handles (Inv. n. 2013.54.20) to 1650-60, and there is also a cooking pot leg (Inv. n. 2013.54.13) bent right back into a spiral. Both fragments are pieces of small cooking pots. Special mention must be made of the fragment of a semi-finished small bowl (Inv. n. 2013.54.23) with thick walls, made of rough-grained, brick-like material, in which a grainy, crystallised material was stored, perhaps the basic material for paint or glaze. There are also a number of badly fired pieces with stained glaze; one of them is part of a lid covered with a white star on a blue base. An intact piece, a hexangular finished product in the shape of a nail with a light blue glaze, used to hold down the corners of wall tiles, is a curiosity (Inv. n. 2013.54.24).

There was no Haban settlement in Holics, only a faience manufactory where Haban potters also worked; this is the reason why none of the fragments were lead-glazed, they were all pieces of tin-glazed pots and kiln furniture. They can all be dated to the second half of the $18^{\text {th }}$ century. ${ }^{7}$ The half-finished pieces of many small pots were made with thin walls from fine, well prepared clay that fired to a pale colour. Almost without exception there is a thin layer of slip beneath the glaze. A few pieces have patches of barely visible burnt out tin glaze. The material from Holics also includes an aid used during firing, a triangular slab that Mária Kresz identifies as a Ständle (stilt). She notes: "It was used to hold the plates in place in the saggar. In Modor (Modra, now Slovakia) too, the same name is used for it." The side wall and a piece of the bottom of a saggar made of extremely thick, rough brick-red material with a white tin glaze in the interior was also part of the gift (Inv. n.s 2013.54.42, 2013.54.43). (Fig. 6) The basic material used for the tin-glazed products in both places is clearly the same: finely prepared clay that fires to a pale light colour and could be used to make vessels with very thin walls. This gives us important information on the production techniques used. There are many fired, unglazed fragments, indicating that the glaze was not applied to the raw, unfired wall of the vessel.

\footnotetext{
${ }^{7}$ The faience manufactory was founded in 1743 by Francis of Lorraine, husband of Maria Theresa. Together with a number of masters brought in from abroad, Habans who had remained here and reverted to Catholicism also worked in it.
} 


\section{SCATTERED WORKSHOPS}

An examination of the large number of faience vessels reveals a few individual pieces that differ from the others in character, decoration elements and their composition. Haban research has paid no attention and has no method for the study of the style and products of the scattered workshops and so has no knowledge of them. Even the vessels made in Alvinc, the Haban centre in Transylvania that turned out products continuously for at least 150 years, have not been unequivocally identified or their style features defined (KLUSCH Roşca 2007, 2010). There was a Haban court that perhaps also operated a pottery workshop, for example in Tamásfalva (Tomášová, now Eastern Slovakia), that has since become part of Rimaszombat (Rimavská Sobota, now Eastern Slovakia) (B. KovÁcs 2001: 25, KATONA 1978: 179). If there was in fact a Haban settlement there, the $18^{\text {th }}$ century large Haban jug of the Rimaszombat bootmakers' guild with an inscription in Hungarian and decorated with a unicorn, deer, rabbit and dog was probably made locally. And there is also a pelican jug in Rimaszombat with a very similar structure, approximately the same age and fired in the same workshop. ${ }^{8}$ Both pieces belong in all their elements to the colourful type that can be defined on the basis of the potter's sign ${ }^{9}$ from Nagylévárd (Vel'ké Leváre, Gross-Schützen, now Western Slovakia, one of the most important and biggest settlements of Haban potters) to be mentioned later, and were probably made in the first half of the $18^{\text {th }}$ century.

Haban masters also worked in Rozsnyó (Rožňava, Rosenau, now Eastern Slovakia). A manufactory also operated there from the 1810s (Katona 1978: 179). A number of fine Haban pieces entered our museum from there - from the collection of Baron Albert Nyáry, historian, archivist and archaeologist. A few pieces entered the Ceramics Collection of the Museum of Ethnography, ${ }^{10}$ and we also have a number of pieces from the vicinity of Rozsnyó. However, it is impossible to identify the local products without an archaeological excavation of the waster pits beside the workshops.

Whether the blue-glazed jugs and plates from Zólyom county (Zvolen, Altsohl, now Slovakia) can be regarded as the products of scattered workshops is an important question. According to the Habans' Hamburg chronicle, Habans also moved to the mining towns in Upper Hungary (SzENDREI 1889: 174). Nevertheless, the literature on the history of the Habans makes no mention of Habans in Zólyom. It would be important to examine the $18^{\text {th }}$ century ceramics of Zólyom county, because it could decide a number of unclarified questions. In his study “Old Hungarian Pottery Wares” Kornél Divald published three plates from the collection of Gyula Thomka, the famous collector from Besztercebánya (Banská Bystrica, Neusohl, now Slovakia). He indicated the nearby Libetbánya (L'ubietová, Libethen, now Slovakia) as the place where they were made (Divald 1917: 11, 29). Later Hungarian ceramics history research identified these as Upper Austrian onion dishes, thereby generating a debate on this type of ceramics (KRESz 1972b: 160).

Dishes of that type were made from the end of the $17^{\text {th }}$ century to the mid- $18^{\text {th }}$ century. In German and Austrian ceramics history they are known as oberösterreichische

\footnotetext{
${ }^{8}$ Divald 1917: Figs. 22 and 23, B. KovÁcs 2001: Figs. X and XI.

${ }^{9}$ http://gyujtemeny.imm.hu/gyujtemeny/cehtabla-a-nagylevardi-fazekasceh-tablaja/2297

${ }^{10}$ Large jug from 1727, Inv. n. 85657 and small jug from 1747, Inv. n. 85658.
} 
Zwiebelschüssel, that is Upper Austrian onion dishes. This type of dish often also appears in large numbers among archaeological finds in places from South-east Germany, along the Danube to Szentendre. In recent years, Austrian researchers have identified a number of workshops and waster pits have been excavated at nine locations in Perg in Upper Austria and six settlements in the vicinity (KALTENBERGER 2011: 911). The type can definitely be linked to that place.

József Huszka, the great figure in Hungarian motif research in the late $19^{\text {th }}$ century, also visited Gyula Thomka on his collecting trips and painted the dishes mentioned together with three other similar pieces, and named them all as being from Libetbánya. ${ }^{11} \mathrm{On}$ the basis of Divald's description (incised contours, the use of faience colours and glazes in the painting) and of coloured images it became convincingly clear that, in spite of certain similarities of style (large motifs covering the entire surface and not taking into account the structure of the dish), these dishes are not the same as the group of onion dishes mentioned, but are fine examples of a regional style of an independent lead-glazed pottery of unknown geographical distribution from the first half of the $18^{\text {th }}$ century. They are from the same period as the Haban type localised to Zólyom county. It would be worth making a study of them together with the ceramics of the Garam valley in the first half of the $18^{\text {th }}$ century, as it is very likely that they influenced each other. Perhaps this is the reason for the distinctive style of the Haban products from Zólyom county. ${ }^{12}$

\section{THE NAGYLÉVÁRD COLOURED TYPE}

Mária Krisztinkovich, the daughter of Béla Krisztinkovich, the famous Haban collector and researcher, and Mária Kresz also noticed that the decorations on the so-called Nagylévárd potter's sign panel dated 1732 can be used to distinguish two types of products (one coloured and the other painted blue). The dated pieces indicate that they were made from the second half of the 1710 s to the mid- $18^{\text {th }}$ century. Dates appear mainly on those with coloured painting, less often on those decorated in blue. ${ }^{13}$ Among the coloured motifs on the sign is a tapering branch with pairs of round leaves and occasionally pairs of yellow berries between them. Bunches of flowers are also characteristic and identifiable. The jug from Rozsnyó (Inv. n. 85658) with the symbols of the cutlers' guild in the collection of the Museum of Ethnography, as well as a jug from Györ with a pewter lid (Fig. 7), ${ }^{14}$ and the potter's mark D on the bottom, belong to this coloured Nagylévárd type. A large jug, one of the oldest objects in the collection, deserves special attention: an image of it also appeared in a study published in $1906^{15}$. It is unusual for its exceptional size - height: 40 $\mathrm{cm}$ - and for the abundance of genre scenes on the side: a noble leatherworker with spurs smoking a pipe and seated on his stool (kaszaszék), a scene of Adam and Eve, an angel

${ }^{11}$ EA Collection of Drawings and Paintings NM R 9720.

${ }^{12}$ On the subject see the study by Ridovics et alie 2015 in this same volume.

${ }^{13}$ These studies in languages other than Hungarian have remained almost unnoticed in Hungarian Haban research. Kresz 1984, KrisztinKovich 2005:183-188, objects 54-56.

${ }^{14}$ Kresz 1972: 227, Figure 7, Inv. n. 51059.

${ }^{15}$ BÁткy 1906: 320-322, Inv. n. 93.8.1. 
holding an animal skin, and two men in conversation. There is also a giant rabbit-like deer, beetles, and a bird among the rich, multi-level floral compositions (Fig. 8), parallels for which can be seen on the Nagylévárd sign panel.

The search in the literature and the various collections for parallels to the Nagylévárd coloured type showed that a small group and area is concerned. None of the pieces were dated later than the mid- $18^{\text {th }}$ century, and none earlier than the $18^{\text {th }}$ century. It is not possible to determine precisely how many workshops in how many Haban settlements were involved, but the undated objects can also be identified well through these motifs.

\section{THE NAGYLÉVÁRD BLUE PAINTED VESSELS}

In the same way as the coloured decorations, the blue motifs around the edge of the Nagylévárd sign can be used to date individual pieces. Even less attempt has been made to distinguish between the Austrian, Southern German, Czech and Moravian manufactories and the Haban products in the case of the pieces with blue decoration than for those with coloured decoration. In this respect it is not always possible to distinguish between the products of the different Austrian manufactories, while Haban research has largely evaded this problem.

Haban ceramics decorated with blue are often said to be the consequence of the diplomatic mission to Delft in 1667, despite the fact that Haban pieces painted blue on a white base have come down to us from before that date. A number of researchers at the Haban conference held in 1981 in Kircheimbolanden were of the opinion that the influence of Delft was only indirect; the South German and Austrian ware with blue and white decoration under the influence of Delft faience in turn had an influence on the Haban products. ${ }^{16}$

However, the decorations on the Nagylévárd sign can be used to define at least a narrower group. The motif in a circular frame on the belly of our pear-shaped jug (Inv. n. 62.181.147) collected in Rozsnyó, as well as the other small blue elements are evidence that the object was contemporary to the Nagylévárd sign. It can also be assumed that they were produced by workshops close to each other or even by the same workshop. The potter's mark on the pear-shaped jug is the letters I L written together, with dots (Fig. 9). A pearshaped jug purchased in Zólyom county, in Gyetva (Detva, now Slovakia) (Inv. n. 13152) has similar painting, and so does a tankard (Inv. n. 60.39.66). The decoration beside the handle and the row of spirals drawn on the handle with a thick line are identical. A similarly decorated pear-shaped jug is known from Northern Hungary ${ }^{17}$ and there is another piece, part of a cellar find from Mannersdorf (Répcekethely, formerly Vas county, now on the border of Burgenland and Lower Austria, not far from the Hungarian border). ${ }^{18}$ Our earliest vessel of this type is a pear-shaped jug (Inv. n. 2542) with the monogram MB on the bottom, and a piece (Inv. n. 50993) with the potter's mark H also belongs in this group.

\footnotetext{
${ }^{16}$ The Amsterdam researcher Irvin B. Horst disputed this direct connection. See: Kresz 1982: 311-314.

17 TAKÁCS 1977: 98, Figure 8.

${ }^{18}$ Grieshofer 2007: 40, Figures 7 and 10.
} 
At least two flat wares must be classified here: one is a small cake plate with a turned base (Inv. n. 51.30.239) and the other, a dish dated 1732 is decorated in the centre with a name and the year in a wreath and it also has a rounded base (Inv. n. 70.37.176). (Fig. 10)

\section{MARBLED DECORATION}

Identification is made especially difficult in the case of marbled, sprinkled, and monochrome blue, green or manganese purple glazed, undecorated vessels by the fact that the majority of the German, Austrian and Czech manufactories also made such wares. Austrian researchers distinguish between them on the basis of the proportions of the body, the shape of the handle and the way it is attached. They consider pear-shaped jugs with narrow necks and long handles reaching down below the belly of the pot, and stretched out smoothly against the body to be Haban ware (PeSCHEL-WACHA 2007: 12). Fragments with blue glaze and marbling occurred frequently among the finds of the excavations at Alvinc (Transylvania). No $17^{\text {th }}$ century pieces were found among them; the circumstances of the find indicate that they must have been made in Transylvania up to approximately 1740 (BunTA 1973: 38). Taking all this into consideration, it can be concluded with near certainty that the three objects are Haban products (Inv. n.s 41659, 51.30.117. pear-shaped jug, Inv. n. 70.37.237). It is impossible to determine whether the others are Haban work or came from Austrian manufactories (Husty-IpeK - Kraiger 1994; Langer 1988; PeschelWACHA 2007; SwOBOda 1999).

It is very difficult to compile an unequivocal collection statistics, because there are many transitional pieces that are hard to classify. Our collection raises a whole series of periodisation and classification problems: the Haban products have not yet been distinguished from the products of Austrian, German and Moravian manufactories; it is difficult to date objects not marked with the year, as we do not know how long certain decorations remained popular; we have, for example, almost entirely identical dishes in the shape of a cardinal's hat with wreaths on the edge, monogram and year from 1683 and 1747.

\section{HABAN GUILD VESSELS}

A number of Haban guild vessels with classical painting have survived from the last third of the $18^{\text {th }}$ century. It is striking that even at the end of the $18^{\text {th }}$ century they still preserve their form, classical style painting and composition from the beginning of the century. This phenomenon is well known from the practice of folk pottery in the $19^{\text {th }}$ century. If a community has come to like a form and decoration that it feels to be its own, it will then preserve it for many decades, consistently and unchanged, regardless of what the current ceramic style may be.

One such striking object type is the communion table wine jug and the guild jug; different regions clung to certain forms and decorations. The form and decoration of vessels having an important function accepted by the community and sanctified by traditions became constant, because the environment that ordered them felt that it was their 
became constant, because the envronment that ordered them felt that it was their representation and continued to order them with unchanged decoration, form and size when the style of the vessels intended for use had long been different. Certain decorative motifs and techniques of decoration continued to live only on such objects, but all potters who worked within the community had to be able to make them faultlessly.

\section{STOVE TILES}

The Museum of Ethnography's collection of stove tiles numbers close to 2500 pieces. The most valuable part of this collection unit is the group of approx. 270 intact, whole tiles, mainly from Transylvania, including a number of dated pieces from the $17^{\text {th }}$ century and many from the $18^{\text {th }}$ century. We also have around 60 undated stove tiles with endless pattern. Several types, mainly among these pieces with endless pattern (BunTA 1984; Cserey 1984; Döry 2003, 2007, 2008; Gyuricza 1992) are of known Haban origin. For the majority of the tiles from Transylvania, it is not possible to determine whether the given piece is a Haban product or the work of a Hungarian or Saxon (ethnic German) master copying Haban tiles. This is the reason why only a few pieces can be identified with certainty as Haban tiles (Inv. n.s 41838, 2007.39.396 , 41807, 41830, 41822 and 78.112.1). And we can be entirely certain for only one of these: together with the raised surface of the tin-glazed tile painted blue with an endless heart pattern - a decoration that was also characteristic of later Transylvanian Saxon tiles - it is the decoration painted with a brush on the flat surface that gives the certainty. In the Carpathian Basin it was only Habans who also painted decorations on the flat surface of their tiles (Inv. n. 2007.39.397). (Fig. 11)

Among the drawings and watercolours in the museum's Collection of Drawings and Prints there are images of Haban vessels that have been destroyed or their whereabouts are unknown. ${ }^{19}$ These too can be seen in the online catalogue on the Museum of Ethnography's website (Fig. 12).

\section{LATE HABAN CERAMICS}

The Budapest Museum of Ethnography's collection is most representative of the settlement period starting from the mid- $18^{\text {th }}$ century, or the Late Haban period. It includes transitional objects, evidence of the change of style, and almost the full range of variations in form and decoration of the Late Haban mass production. The Late Haban collection is excellent for research on style changes and following parallels, and the final disappearance of old decorative elements.

Mária Kresz began to process this vast quantity of ceramics in the frame of an international project. The research on "Die Hutterischen Täufer. Geschichtlicher Hintergrund und Handwerkliche Leistung” was organised by the Hafner Archive of the Ethnographical Department of the Bavarian National Museum and the Mennonitische Forschungstelle,

${ }^{19}$ Collection of Drawings and Prints EA-NM R 9723. 
and directed by the late Ingolf Bauer. The countries participating were Canada, USA, what was then the FRG, the Netherlands, Switzerland, Austria, Italy, what was then Czechoslovakia, Romania and Hungary. All the best known and most outstanding researchers in the field took part in the project. The papers presented at the Haban conference held in 1981 in Kircheimbolanden were published in German in vol. 104, 1984 of the journal Keramos. The big-name participants died before the results were published. They were not able to complete the work. Leafing through the notes Mária Kresz left, it is obvious that separating the vast amount of objects had posed the most problems for her and was her most difficult task: "we are unable to distinguish the Lower Austrian material from the Moravian," she wrote. ${ }^{20}$ "The faience technique used by the Habans was adopted in a number of centres, where Haban families had never lived, or where only a few of the potters were descended from the Habans." ${ }^{21}$ This means that most of the $19^{\text {th }}$ century material is not Late Haban ware. There was no Haban settlement in Modor (Modra, Modern, now Slovakia), a place renowned for its faience manufactory and where the factory still operates. "The faience from Stomfa (Štupava, Stampfen, Western Slovakia) also goes back only in part to Haban traditions. This question is very complicated and is an interesting problem of research in Czechoslovakia," she noted, ${ }^{22}$ and we can add that the task remains unsolved.

Not only did the Haban ceramics influence each other, in cases they also affected the style of products from Austrian and German manufactories, where the first generation of masters included a number of Haban potters who had reverted to Catholicism. Naturally, the style of the Habans did not resist the big market demands found throughout Central Europe and the ceramics fashions, but rather adapted to them: they began to copy the Austrian and German faience products of the period. The result of these mutual fashion influences was the lead-glazed pottery produced from the late $18^{\text {th }}$ century to the first half of the $19^{\text {th }}$ century and it is almost impossible to determine, whether certain types of small jugs or bowls were the products of Haban, Gmunden, Frankfurt, Gera or other South German or Lower Austrian (for example Leobersdorf) or perhaps Burgenland manufactories.

It is thus almost impossible to group Late Haban pieces by the place where they were made. Although the majority of $18^{\text {th }}$ century products have a potter's mark on the bottom, many family names began with the same letter and family names are repeated over the years, as the craft is passed down within the family. Because families frequently moved and family members split off, even with research in the records of births, marriages and deaths it is not always possible to identify a workshop with certainty. In this area, excavations in the Haban settlements, especially an examination of the monograms on wasters discarded during firing and making, and a critical analysis of their style could together produce results.

${ }^{20}$ Notes made by Mária KRESZ, uninventoried material, accession number AEA 8/2012, Manuscript Collection.

${ }^{21}$ Notes made by Mária KRESz, uninventoried material, accession number AEA 8/2012, Manuscript Collection. For a study titled $A$ habán kutatás néprajzi vonatkozásainak újabb eredményei [New results on the ethnological aspects of Haban research] dedicated to the memory of Béla Krisztinkovich.

${ }^{22}$ Papers of Mária Kresz. Ethnological Archive accession number 8/2012, uninventoried. She refers here to two books by Alzbeta Güntherová-Mayerova: Slovenska keramika, Martin, 1942, and Ludové umenie na Západnom Slovensku, Zápodoslovenské Múzeum v. Trnavé, 1966. I. 
In the frame of the international Haban research project, Mária Kresz drew up systematised lists based on the collecting places, the presumed production places, and chronological order. We can see from the inventory cards of the objects, her notes on the shelves of grouped objects, and her lists that she must have had more precise ideas on the production places for the typification and identification of the decorations. However, the diversity of the collection purchased in Habanszki Dvor, Szobotist is a reminder of the relative nature of style criticism and the danger of errors.

She produced only two publications from the international research, both in German and both published abroad. One is the only study that presents the Museum of Ethnography's classical Haban pieces (KRESz 1983). The other is the paper she presented at the Kircheimbolanden conference, in which she wrote about the distribution of Museum of Ethnography's Late Haban ware on the basis of the places where the pieces were collected and used (Kresz 1984). She demonstrated on this basis that Late Haban faience products were both popular and sought after in the entire Hungarian-speaking territory in the first half of the $19^{\text {th }}$ century. It is also clear that far fewer of these pieces were found in settlements on the Great Plain than in Northern Hungary or Transylvania, where they had an especially big market.

Future research in the inventories will be able to show from what point in time households of the common people began to use Haban ware and in what regional distribution. It remains to be seen whether this information will also show the types and decorations of Early Haban pieces that reached the common people. Probably we will only have an unequivocal answer to this question, too, when organised archaeological excavations are held in the villages and small towns.

\section{LITERATURE}

N. N.

1906: Útmutató Néprajzi Múzeumok szervezésére. [Guide to the organisation of museums of ethnography.] Múzeumi és könyvtári kézikönyvek. Múzeumok és Könyvtárak Országos Felügyelősége, Budapest.

BENDA Borbála

2004: Étkezési szokások a 17. századi fóúri udvarokban Magyarországon. [Dietary customs in $17^{\text {th }}$ century aristocratic courts in Hungary.] Eötvös Loránd Tudományegyetem Bölcsészettudományi Kar. (Doctoral dissertation, published digitally.) Accessed at: http://archivum.piar.hu/batthany/benda

B. KovÁcs István

2001: Agyagkenyér. Fejezetek az agyagmüvesség történetéböl Gömörben és Kishontban. [Clay bread. Chapters from the history of ceramics in Gömör and Kishont counties.] Rimaszombat.

Bunta Magda

1973: Az erdélyi habán kerámia. [Haban ceramics in Transylvania.] Kriterion, Bucharest.

1984: Die Habaner in Siebenbürgen. Keramos. Zeitschrift der Gesellschaft der Keramikfreunde E.V. Düsseldorf. Heft 104, 79-85.

Csemegi József

1957: Trinitász-szimbólumok és ábrázolások a középkori Magyarország művészetében, eredetük, továbblépésük és népmüvészeti kapcsolataik. [Trinity symbols and portrayals in mediaeval Hungarian art, their origin, further forms and folk art connections.] In: Müvészettörténeti tanulmányok. A Müvészettörténeti Dokumentációs Központ évkönyve 1954-1955. Dávid, Katalin (ed.) Budapest, Képzőmüvészeti Alap, 7-45. 
CSEREy Éva

1984: Gedanken zu Habaner-Kacheln im Kinstgewerbemuseum in Budapest. Keramos 104. Heft. 86-96. Csupo István

2000: Kerámiagyüjtemény. [Ceramics collection.] In: FEJŐS Zoltán (ed.): A Néprajzi Múzeum Gyüjteményei. Budapest, Néprajzi Múzeum, 261-299.

Divald Kornél

1917a: Régi magyar fazekasmunkák. [Old Hungarian pottery.] In: SikLóssy, László (ed.): Holics, Tata, Stomfa Bp. 11-35.

1917b: Régi magyar népies fajanszok. [Old Hungarian folk-style faience.] In: SiKLóssy, László (ed.) Holics, Tata, Stomfa 1-10. Budapest.

DörY, Ludwig Von BARON

2003: Vergessene und unbekannte Habaneröfen. In: Keramik als Zeichen regionaler identität. Beiträge des 36. Internationalen Hafnerei-Symposiums des Arbeitskreises für Keramikforschung vom 21. bis 26.9.2003. In Kittsee. Kittseer Schriften zur Volkskunde Bd. 16. Wien/Kittsee 2005. S. 185-206.

2007: Sechs Ofenkacheln-Typen und ihre Wanderung von West nach Ost. In: Karla RoșCA - Horst KLUSCH (eds.) Keramische Oberflächen und ihre Gestaltung. Sibiu 2007. Editura: Astra Museum, 24-40.

2008: Hat kályhacsempetípus vándorlása nyugatról keletre (16-17. század). [The migration of six stove-tile types from West to East.] Herman Ottó Múzeum Évkönyve XLVII. 593-616.

Gyuricza Anna

1992: Reneszánsz kályhacsempék Északkelet-Magyarországról. [Renaissance stove tiles from North-east Hungary.] Miskolc.

GRIESHOFER, Franz

2007: Chinoiserien in blau ein Fayencefund aus Mannersdorf in Niederösterreich.. In: Karla RoșcA - Horst KLusch (eds.) Keramische Oberflächen und ihre Gestaltung. Sibiu 2007. Editura: Astra Museum, $41-45$.

Horváth, J. Eugene - Krisztinovich, Maria H.

2005: A history of Haban ceramics, A private view. Vancouver, Vancouver BC Canada.

Husty, Peter - IPek-Kraiger, Esra

1994: Blau auf weiß. Süddeutsche Fayencen aus der Sammlung des Salzburger Museums C.A.Katalog. Schriftenreihe zu Kunstgewerbe und Volkkunde. Band 1. Salzburg, Salzburger Museum.

KaLtenberger, Alice

2009: Keramik des Mittelalters und der Neuzeit in Oberösterreich. Studien zur Kulturgeschichte von Oberösterreich. Folge 23. Band 1-2. Bibliothek der Provinz.

KATONA Imre

1978: A magyar kerámia és porcelán. [Hungarian ceramics and porcelain.] Budapest, Képzőművészeti Alap Kiadóvállalata.

KLusch, Horst - RoşCA, Carla

2007: Keramische Oberflächen und ihre Gestaltung. Sibiu 2007. Editura: Astra Museum.

2010: Keramikerzeugnisse der Zünfte, der Manufakturen, der Habaner Werkstatt aus Siebenbürgen, Sibiu, Honterus.

Kresz Mária

1972b: Borsod megyei fazekasság. [Pottery in Borsod county.] Herman Ottó Múzeum Közleményei 11. $157-167$.

1977: A Néprajzi Múzeum Kerámiagyüjteménye. (A kutatás és a gyüjtés története). [The Museum of Ethnography's Ceramics Collection. (Research and collecting history).] I: Néprajzi Értesitö, LIX. 17-39.

1982: Konferencia a hutteriták történetéről és a habán kerámiáról Kircheimbolanden 1981. [Conference on the history of the Hutterites and Haban ceramics. Kirchheimbolanden, 1981.] Ethnographa, XCIII. 311-314.

1983: Die Verbreitung der Spät-Habaner Fayence des 18. Jahrhunderts in Ungarn -dargestellt am Material des Ethnographischen Museums in Budapest. Keramik Freunde der Schweiz, Mitteilungsblatt, 98, 1983, Sept. 5-12. 
1984: Verbreitung der Volkstümlichen Habaner-Fayencen in Ungarn Nach dem Material des Ethnographischen Museums in Budapest. Keramos, Zeitschrift der Gesellschafft der Keramikfreunde. Heft 104, April, Düsseldorf.

LANGER, Hermann

1988: Österreichische Fayencen. München, Weltkunst Verlag.

Peschel-Wacha, Claudia

2007: "Marmorierte" Fayencen aus der Barockzeit. Forschungen Rund um diese Dekorart Anhand von Beispielen aus dem Österreichischen Museum für Volkskunde in Wien und dem Kittseer Kellerfund. In: Karla Roșca - Horst Kuusch (eds.) Keramische Oberflächen und ihre Gestaltung. Sibiu, Editura: Astra Museum, 11-16.

RadváNYi Diána - RÉTI László

2011: A habánok kerámiamüvészete. [The ceramic art of the Habans.] Budapest, Novella.

RÉTi László

2007: Habán mítosz 1593-1738. [Haban myth, 1593-1738.] Budapest, Iparmüvészeti Múzeum.

Ridovics, Anna - MAY, Zoltán - BAJNÓCZI, Bernadett - TÓTH, Mária

2015: Examination of haban vessels with uranium bearing blue glaze. Acta Ethnographica Hungarica 2015/2. 485-514.

Svoboda, Christa

1999: Blau Welle - grüner Flamme. Salzburger und Gmundner Fayencen 17.- 19. Jahrhundert. Katalog zur Sonderausstellung im Carolino Augusteum. Salzburg, Carolino Augusteum, Salzburger Museum für Kunst und Kulturgeschichte.

SzENDREI János

1889a: A habánok története Magyarországon és a habán majolika. [History of the Habans in Hungary and Haban majolica.] Müvészi Ipar, 161-176.

1889b: Felső-Ausztriai hagymástálak az Iparmủvészeti Múzeumban. [Onion bowls from Upper Austria in the Museum of Applied Arts.] Müvészi Ipar, 142-144.

TAKÁCS Béla

1977: Habán edények észak-magyarországi templomokban. [Haban vessels in churches of Northern Hungary.] Herman Ottó Múzeum Évkönyve 16, 185-204.

VIDA Gabriella

2008a: Habán fajanszok. Díszedények. [Haban faience. Decorative pieces.] In: Fesős Zoltán (ed.) Legendás lények, varázslatos virágok-a közkedvelt reneszánsz. Exhibition in Néprajzi Múzeum. 164-166, 191-206.

2008b: Kályhacsempék. [Stove tiles.] In: Fejös Zoltán (ed.) Legendás lények, varázslatos virágok-a közkedvelt reneszánsz. Exhibition in Néprajzi Múzeum. 164-166, 191-206. 


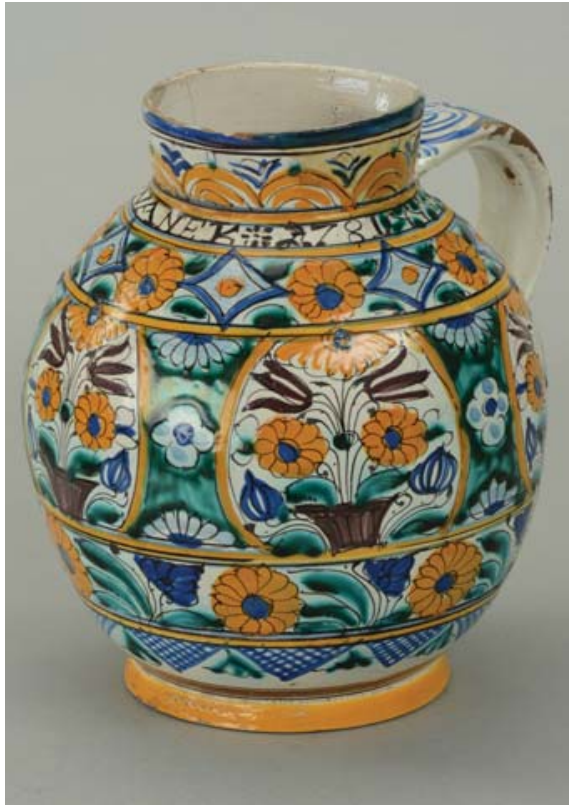

Fig. 1. Large jug, 1781, from the Habanszki Dvor, Szobotist. Inv. n. 28880.

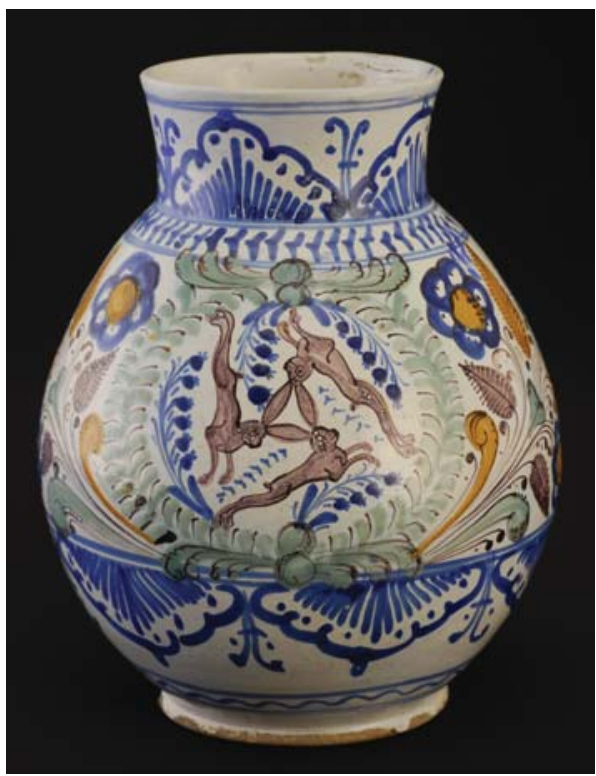

Fig. 3. Large jug, 1700. Inv. n. 101912.

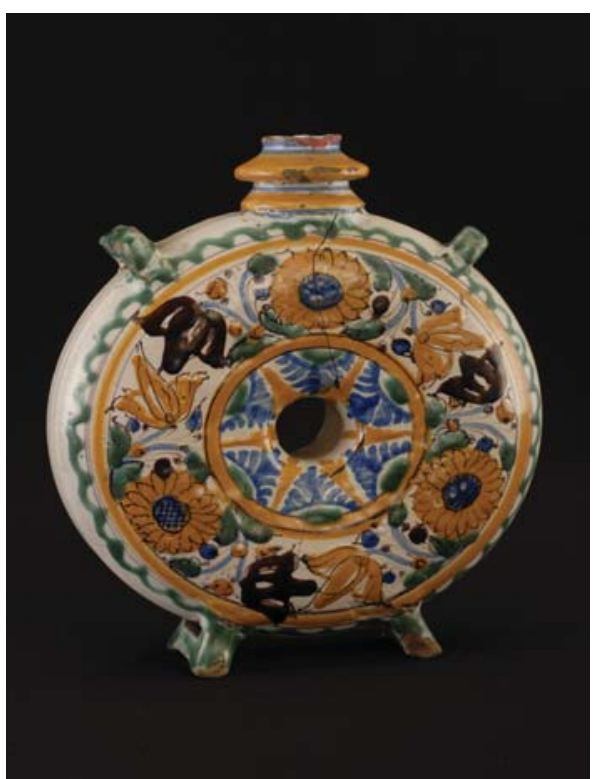

Fig. 2. Ring-shaped flask from the Habanszki Dvor, Szobotist. Inv. n. 28882.

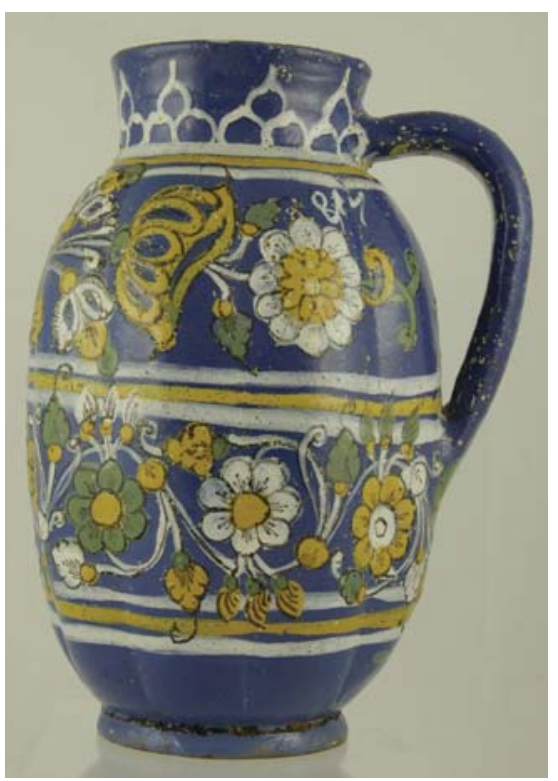

Fig. 4. Large jug, 1708, Alvinc (?), Inv. n. 91.45.1. 


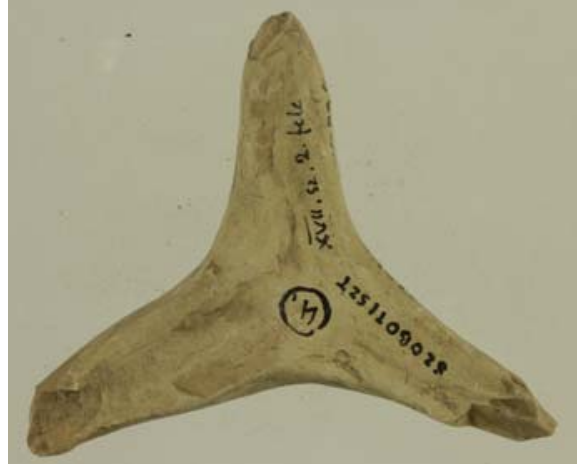

Fig. 5. Stilt used during firing. Szobotist, around 1650-1660. Inv. n. 2013.45.18.

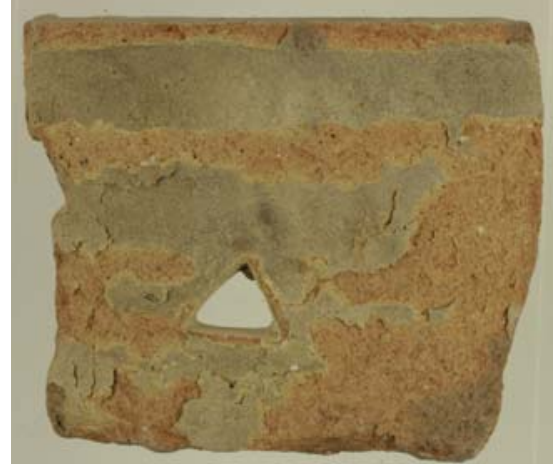

Fig. 6. Piece of a saggar used during firing, Holics, second half of the 18th century. Inv. n. 2013.54.42.

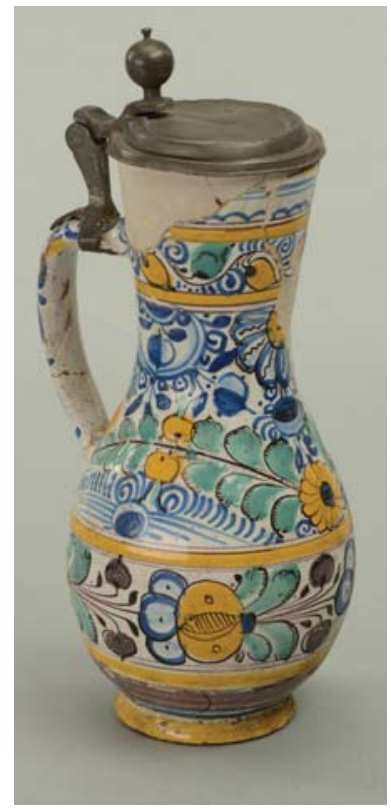

Fig. 7. Pear-shaped jug with Nagylévárd coloured decoration, first half of the $18^{\text {th }}$ century. Inv. n. 51059. 


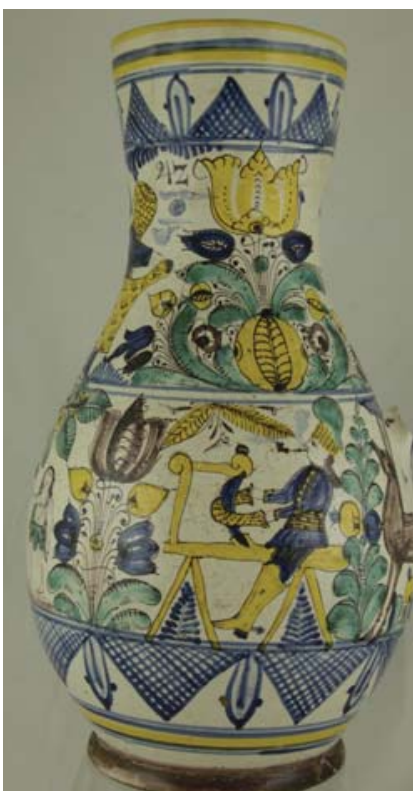

Fig. 8. Large pear-shaped jug with scenes, 1742. Inv. n. 93.8.1.

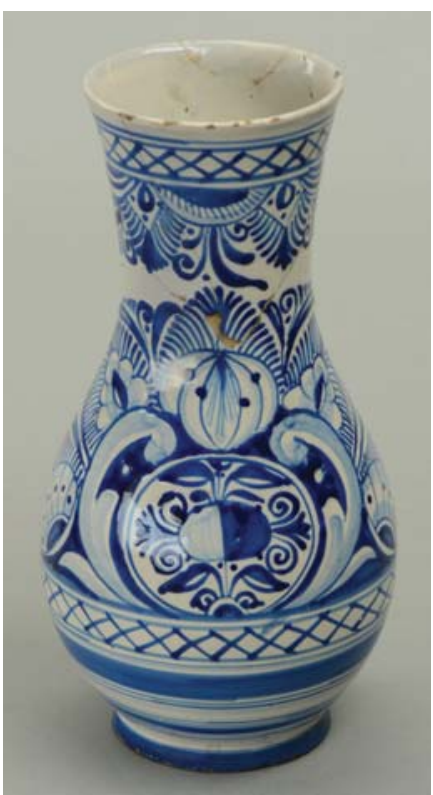

Fig. 9. Pear-shaped jug with Nagylévárd blue decoration, first half of the $18^{\text {th }}$ century. Inv. n. 62.181.147.

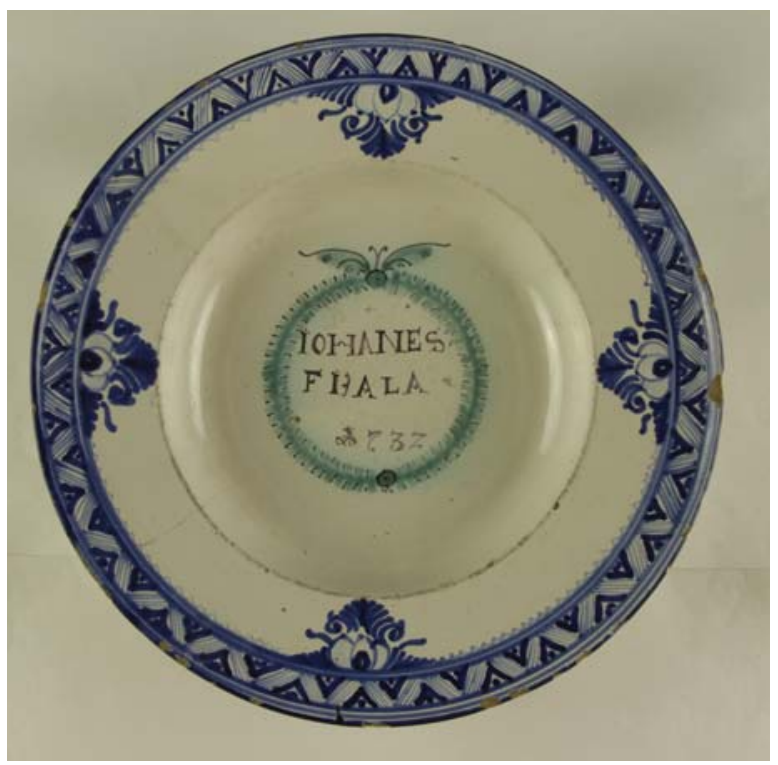

Fig. 10. Dish with Nagylévárd blue decoration around the rim, 1732. Inv. n. 70.37.176. 


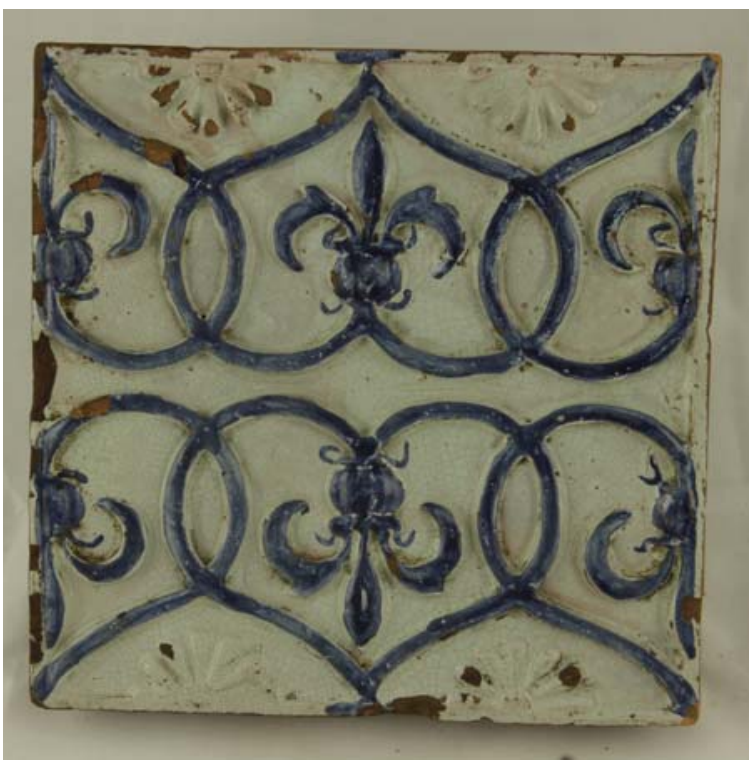

Fig. 11. Haban tile with endless pattern, last third of the $17^{\text {th }}$ century. Collected in Transylvania. Inv. n. 2007.39.397.

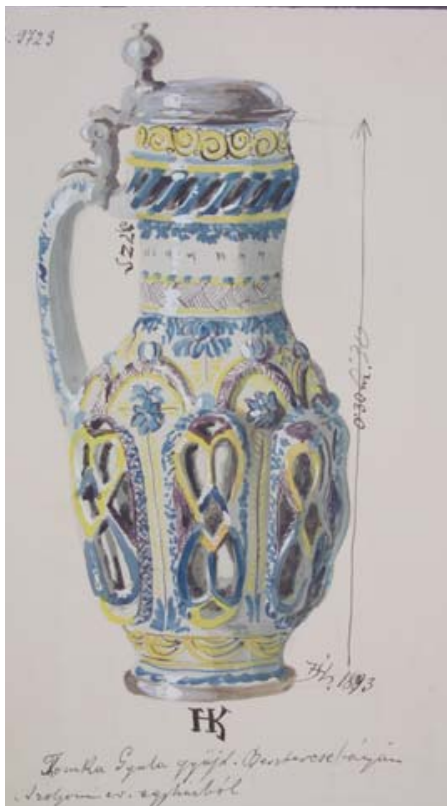

Fig. 12. Pear-shaped jug with pewter lid, 1725,

from Besztercebánya. Painting by József Huszka, 1893. Inv. n. EA-NMR 9723. 